\title{
A new lizard malaria parasite Plasmodium intabazwe n. sp. (Apicomplexa: Haemospororida: Plasmodiidae) in the Afromontane Pseudocordylus melanotus (Sauria: Cordylidae) with a review of African saurian malaria parasites
}

\author{
Johann van As ${ }^{1}$, Courtney A. Cook ${ }^{2 *+}$, Edward C. Netherlands ${ }^{2,3+}$ and Nico J. Smit ${ }^{2+}$
}

\begin{abstract}
Background: Saurian malaria parasites are diverse apicomplexan blood parasites including the family Plasmodiidae Mesnil, 1903, and have been studied since the early 1900s. Currently, at least 27 species of Plasmodium are recorded in African lizards, and to date only two species, Plasmodium zonuriae (Pienaar, 1962) and Plasmodium cordyli Telford, 1987, have been reported from the African endemic family Cordylidae. This paper presents a description of a new malaria parasite in a cordylid lizard and provides a phylogenetic hypothesis for saurian Plasmodium species from South Africa. Furthermore, it provides a tabular review of the Plasmodium species that to date have been formally described infecting species of African lizards.

Methods: Blood samples were collected from 77 specimens of Pseudocordylus melanotus (A. Smith, 1838) from Platberg reserve in the Eastern Free State, and two specimens of Cordylus vittifer (Reichenow, 1887) from the Roodewalshoek conservancy in Mpumalanga (South Africa). Blood smears were Giemsa-stained, screened for haematozoa, specifically saurian malaria parasites, parasite stages were photographed and measured. A small volume was also preserved for TEM studies. Plasmodium and Haemoproteus primer sets, with a nested-polymerase chain reaction (PCR) protocol, were employed to target a fragment of the cytochrome-b (cyt-b) gene region. Resulting sequences of the saurian Plasmodium species' isolates were compared with each other and to other known Plasmodium spp. sequences in the GenBank database.

Results: The presence of $P$. zonuriae in both specimens of the type lizard host $C$. vittifer was confirmed using morphological characteristics, which subsequently allowed for the species' molecular characterisation. Of the 77 P. melanotus, 44 were parasitised by a Plasmodium species, which when compared morphologically to other African saurian Plasmodium spp. and molecularly to $P$. zonuriae, supported its description as a new species Plasmodium intabazwe n. sp.

(Continued on next page)
\end{abstract}

\footnotetext{
* Correspondence: apicomplexan@yahoo.co.za

${ }^{\dagger}$ Equal contributors

${ }^{2}$ Unit for Environmental Sciences and Management, North-West University,

Potchefstroom, South Africa

Full list of author information is available at the end of the article
} 
(Continued from previous page)

Conclusions: This is the first morphological and molecular account of Plasmodium species within the African endemic family Cordylidae from South Africa. The study highlights the need for molecular analysis of other cordylid Plasmodium species within Africa. Future studies should also include elucidating of the life-cycles of these species, thus promoting the use of both morphological and molecular characteristics in species descriptions of saurian malaria parasites.

Keywords: Plasmodiid taxonomy, Molecular characterisation, Morphological description, Plasmodium zonuriae, Haematozoa, Haemosporids, Malaria

\section{Background}

Saurian malaria parasites are diverse apicomplexan blood parasites including the family Plasmodiidae Mesnil, 1903, and have been reported and described from a range of vertebrates since the early 1900s, see [1]. Reptilian malaria parasites have in the past been represented by four genera: Plasmodium Marchiafava \& Celli, 1885; Haemoproteus Kruse, 1890; Saurocytozoon Lainson \& Shaw, 1969; and Haemocystidium Castellani \& Willey, 1904. However, species of Haemoproteus infecting reptiles (lizard, snake and chelonian) have recently been proposed to belong, on both a morphological and molecular basis, to the resurrected genus Haemocystidium during the revision of the haemoproteid genera by Pineda-Catalan et al. [2]. These genera, as well as the subgenera Sauramoeba Garnham, 1966; Carinamoeba Garnham, 1966; Lacertamoeba Telford, 1988; Paraplasmodium Telford, 1988; Asiamoeba Telford, 1988; Garnia Lainson, Landau \& Shaw, 1971; and Ophidiella Garnham, 1966, were in the past solely differentiated by the morphology of the erythrocytic stages and development in the tissues of the vertebrate host, as well as by the development in the haematophagous vector [1]. The first saurian Plasmodium species, Plasmodium agamae Wenyon, 1909 and Plasmodium mabuiae Wenyon, 1909, were described by Weynon (1909) from an agamid lizard (Agama agama) and from a scincid lizard (Trachylepis quinquetaeniata) in Africa, respectively. On a global scale, Plasmodium species descriptions remained rare until the 1960 s when research on these organisms greatly increased $[3,4]$. Today, at least 27 species of Plasmodium are recorded from African lizards, but only two species have been described from African cordylid lizards (Table 1).

The first saurian malaria parasite from South Africa, Plasmodium zonuriae (Pienaar, 1962), was described from a cordylid lizard (Cordylus vittifer) collected at Elandsfontein (North-West province) [5]. Following the original description by Pienaar [5], an additional host, Pseudocordylus microlepidotus (Cuvier, 1829), collected in 1972, and locality, the vicinity of Cape Town (WesternCape province), was recorded for this malaria parasite [6]. Later, in 1986, specimens of the type-host (C. vittifer) from roughly the same region as the type-locality as well as further north within South Africa (Pretoria region), were confirmed positive for $P$. zonuriae, thereby again increasing the distribution range of this parasite [6]. In his review on haemoparasites of the reptilia, Telford [6] reported a second species of Plasmodium, collected from South African C. vittifer, Plasmodium cordyli Telford, 1987; a parasite which he had originally described from Cordylus tropidosternum in Tanzania [6, 7]. Thus, by 2009, two species of Plasmodium had been described and reported parasitising cordylid lizards of South Africa, namely P. zonuriae from both $C$. vittifer and P. microlepidotus and P. cordyli from C. vittifer [6].

The majority of malaria parasite species descriptions in African lizards were based on the morphology of the intraerythrocytic parasites, and new species were often named based on new host infection records. This is equally true for other apicomplexan blood parasites such as the haemogregarines. However, recently there has been a concerted effort to describe known and new species of haemogregarines from African lizards using both morphological and molecular methods (see [8]). In this study we intended to do the same for three species of African saurian malaria parasites and as such the aim of this study was to morphologically confirm and molecularly characterise the two Plasmodium species, $P$. zonuriae and $P$. cordyli, reported infecting South African cordylids, review all existent saurian malaria parasites based on their morphometrics and describe, name and molecularly diagnose an unknown species of Plasmodium parasitising the South African Afromontane cordylid species Pseudocordylus melanotus.

\section{Methods}

Lizard collection, blood smear preparation and screening Specimens of Pseudocordylus melanotus $(n=77)$ were collected by hand during the summer months (September to April), over a period of 5 years (2008-2013), at Platberg Reserve $\left(28^{\circ} 14^{\prime} 36.71^{\prime \prime} \mathrm{S}, 2^{\circ} 09^{\prime} 45.45^{\prime \prime} \mathrm{E}\right)$ in the Eastern Free State Province, South Africa. Additionally, specimens of Cordylus vittifer $(n=2)$ were collected by hand in the Roodewalshoek Conservancy $\left(25^{\circ} 00^{\prime} 51.20^{\prime \prime} \mathrm{S}, 30^{\circ}\right.$ $\left.19^{\prime} 23.17^{\prime \prime E}\right)$ (1441 m), Mpumalanga, South Africa.

Blood was taken with an insulin syringe from the femoral arteries or veins and lizards were immediately released thereafter at the site of capture. Thin blood smears were prepared, air-dried, fixed and stained using Giemsa- 
Table 1 African saurian malaria species across the families Agamidae, Chamaeleonidae, Cordylidae, Gekkonidae, Lacertidae, Opluridae and Scincidae

\begin{tabular}{|c|c|c|c|c|c|c|c|}
\hline $\begin{array}{l}\text { Lizard host species by } \\
\text { family }\end{array}$ & Plasmodiid species & $\begin{array}{l}\text { Original host } \\
\text { localities }\end{array}$ & $\begin{array}{l}\text { Intracellular meront } \\
\text { dimensions }(L \times W \text { in } \mu m) \text {; } \\
{\left[L W \text { in } \mu m^{2}\right] \text {; }} \\
\text { Number of merozoites }\end{array}$ & $\begin{array}{l}\text { Intracellular gametocyte } \\
\text { dimensions }(L \times W \text { in } \mu \mathrm{m}) \text {; } \\
{\left[\mathrm{LW} \text { in } \mu \mathrm{m}^{2}\right]}\end{array}$ & $\begin{array}{l}\text { Gametocyte } \\
\text { morphology }\end{array}$ & $\begin{array}{l}\text { Effects of gametocytes } \\
\text { on host cell }\end{array}$ & Reference \\
\hline \multicolumn{8}{|l|}{ Agamidae } \\
\hline $\begin{array}{l}\text { Agama agama [syn. Agama } \\
\text { colonorum (Linnaeus, 1758)] } \\
\text { Other hosts: Agama } \\
\text { cyanogaster (Southgate, 1970); } \\
\text { Agama mossambica } \\
\text { (Peters, 1854) }\end{array}$ & $\begin{array}{l}\text { Plasmodium (Sauramoeba) } \\
\text { giganteum Theiler, } 1930\end{array}$ & Gbanga, Liberia & $\begin{array}{l}(9-18 \times 4-11) \\
{[52-165]} \\
28-74\end{array}$ & $\begin{array}{l}(9-22 \times 4-10) \\
{[45-145]} \\
-\end{array}$ & $\begin{array}{l}\text { Round to } \\
\text { elongate } \\
\text { or bulky }\end{array}$ & & {$[3,27-29]$} \\
\hline $\begin{array}{l}\text { Agama agama } \\
\text { Other hosts: Acanthocercus } \\
\text { atricollis (Smith, 1849); } \\
\text { Agama hispida aculeata } \\
\text { (Kaup, 1827) }\end{array}$ & $\begin{array}{l}\text { Plasmodium (Lacertamoeba) } \\
\text { agamae (Wenyon, 1909) }\end{array}$ & $\begin{array}{l}\text { Bahr-El-Ghazal } \\
\text { Province, Sudan }\end{array}$ & $\begin{array}{l}(4-11 \times 3-6) \\
{[12-55]} \\
4-15\end{array}$ & $\begin{array}{l}(6-19 \times 3-8) \\
{[33-105]} \\
-\end{array}$ & & $\begin{array}{l}\text { Hypotrophy } \\
\text { Distortion of host cells } \\
\text { Displacement and } \\
\text { occasional distortion } \\
\text { of nuclei }\end{array}$ & $\begin{array}{l}{[3,5,27-} \\
32]\end{array}$ \\
\hline Agama mossambica & $\begin{array}{l}\text { Plasmodium (Lacertamoeba) } \\
\text { mossambica Telford, } 2009\end{array}$ & $\begin{array}{l}\text { Morogoro Region, } \\
\text { Tanzania }\end{array}$ & $\begin{array}{l}(5-15 \times 3-7) \\
{[20-75]} \\
6-34\end{array}$ & $\begin{array}{l}(6-17 \times 3-8) \\
{[36-84]} \\
-\end{array}$ & Elongate & $\begin{array}{l}\text { Distortion of host cells } \\
\text { Displacement and } \\
\text { occasional distortion } \\
\text { of nuclei } \\
\text { Displacement of nuclei }\end{array}$ & [6] \\
\hline Agama mossambica & $\begin{array}{l}\text { Plasmodium (Sauramoeba) } \\
\text { giganteum Theiler, } 1930\end{array}$ & $\begin{array}{l}\text { Gbanga, } \\
\text { Liberia }\end{array}$ & $\begin{array}{l}(9-18 \times 4-11) \\
{[52-165]} \\
28-74\end{array}$ & $\begin{array}{l}(9-22 \times 4-10) \\
{[45-145]} \\
-\end{array}$ & Dimorphic & $\begin{array}{l}\text { Hypertrophy } \\
\text { Distortion and occasional } \\
\text { enlargement of host cell }\end{array}$ & [27] \\
\hline \multicolumn{8}{|l|}{ Chamaeleonidae } \\
\hline $\begin{array}{l}\text { Chamaeleo brevicornis } \\
\text { Günther, } 1879 \\
\text { Other host: Calumma } \\
\text { parsoni crucifer (Cuvier, 1824) }\end{array}$ & $\begin{array}{l}\text { Plasmodium (Sauramoeba) } \\
\text { robinsoni (Brygoo, 1962) } \\
\text { Telford \& Landau, 1987 }\end{array}$ & $\begin{array}{l}\text { Moramanga } \\
\text { Subprefecture, } \\
\text { Madagascar }\end{array}$ & $\begin{array}{l}(11-23 \times 7-11) \\
{[90-184]} \\
40-74\end{array}$ & $\begin{array}{l}(9-20 \times 5-13) \\
{[72-221]} \\
-\end{array}$ & $\begin{array}{l}\text { Oval to } \\
\text { elongate } \\
\text { or bulky }\end{array}$ & $\begin{array}{l}\text { Hypertrophy } \\
\text { Displacement and } \\
\text { distortion of nuclei }\end{array}$ & [33] \\
\hline Chamaeleo brevicornis & $\begin{array}{l}\text { Plasmodium (Lacertamoeba) } \\
\text { brygooi Telford \& Landau, } 1987\end{array}$ & Périnet, Madagascar & $\begin{array}{l}(6-9 \times 5-8) \\
{[36-64]} \\
10-16\end{array}$ & $\begin{array}{l}(9-15 \times 5-10) \\
{[66-126]} \\
-\end{array}$ & $\begin{array}{l}\text { Oval or } \\
\text { elongate }\end{array}$ & $\begin{array}{l}\text { Hypertrophy } \\
\text { Distortion of cell } \\
\text { Displacement and } \\
\text { distortion of nuclei }\end{array}$ & [33] \\
\hline $\begin{array}{l}\text { Kinyongia fischeri } \\
\text { (Reichenow, 1887) }\end{array}$ & $\begin{array}{l}\text { Plasmodium (Sauramoeba) } \\
\text { acuminatum Pringle, } 1960\end{array}$ & $\begin{array}{l}\text { Tanga Region, } \\
\text { Tanzania }\end{array}$ & $\begin{array}{l}- \\
- \\
-\end{array}$ & $\begin{array}{l}- \\
- \\
-\end{array}$ & & Displacement of nuclei & [34] \\
\hline Kinyongia fischeri & $\begin{array}{l}\text { Plasmodium (Lacertamoeba) } \\
\text { fischeri Ball \& Pringle, } 1965\end{array}$ & $\begin{array}{l}\text { Tanga Region, } \\
\text { Tanzania }\end{array}$ & $\begin{array}{l}(9 \times 6) \\
{[50]} \\
21-25\end{array}$ & $\begin{array}{l}(8-11 \times 5-8) \\
{[41-87]} \\
-\end{array}$ & $\begin{array}{l}\text { Oblong to } \\
\text { elongate }\end{array}$ & $\begin{array}{l}\text { Distortion of host cell } \\
\text { Displacement of nuclei }\end{array}$ & [35] \\
\hline $\begin{array}{l}\text { Kinyongia oxyrhina } \\
\text { (Klaver \& Böhme, 1988) }\end{array}$ & $\begin{array}{l}\text { Plasmodium (Sauramoeba) } \\
\text { michikoa Telford, } 1988\end{array}$ & $\begin{array}{l}\text { Kilombero district, } \\
\text { Tanzania }\end{array}$ & $\begin{array}{l}(6-15 \times 4-8) \\
{[28-78]} \\
12-32\end{array}$ & $\begin{array}{l}(6-14 \times 4-8) \\
{[36-80]} \\
-\end{array}$ & Elongate & Hypotrophy & [36] \\
\hline Kinyongia oxyrhina & $\begin{array}{l}\text { Plasmodium (Lacertamoeba) } \\
\text { gologoloense Telford, } 1988\end{array}$ & $\begin{array}{l}\text { Morogoro Region, } \\
\text { Tanzania }\end{array}$ & $\begin{array}{l}(5-7 \times 4-6) \\
{[20-42]} \\
6-14\end{array}$ & $\begin{array}{l}(5-11 \times 4-6) \\
{[20-54]} \\
-\end{array}$ & $\begin{array}{l}\text { Ovoid or } \\
\text { round }\end{array}$ & Displacement of nuclei & [36] \\
\hline
\end{tabular}


Table 1 African saurian malaria species across the families Agamidae, Chamaeleonidae, Cordylidae, Gekkonidae, Lacertidae, Opluridae and Scincidae (Continued)

\begin{tabular}{|c|c|c|c|c|c|c|c|}
\hline $\begin{array}{l}\text { Lizard host species by } \\
\text { family }\end{array}$ & Plasmodiid species & $\begin{array}{l}\text { Original host } \\
\text { localities }\end{array}$ & $\begin{array}{l}\text { Intracellular meront } \\
\text { dimensions }(\mathrm{L} \times \mathrm{W} \text { in } \mu \mathrm{m}) \text {; } \\
{\left[\mathrm{LW} \text { in } \mu \mathrm{m}^{2}\right]} \\
\text { Number of merozoites }\end{array}$ & $\begin{array}{l}\text { Intracellular gametocyte } \\
\text { dimensions }(L \times W \text { in } \mu \mathrm{m}) \\
{\left[\mathrm{LW} \text { in } \mu \mathrm{m}^{2}\right]}\end{array}$ & $\begin{array}{l}\text { Gametocyte } \\
\text { morphology }\end{array}$ & $\begin{array}{l}\text { Effects of gametocytes } \\
\text { on host cell }\end{array}$ & Reference \\
\hline $\begin{array}{l}\text { Trioceros werneri } \\
\text { (Tornier, 1899) }\end{array}$ & $\begin{array}{l}\text { Plasmodium (Lacertamoeba) } \\
\text { tanzaniae Telford, } 1988\end{array}$ & $\begin{array}{l}\text { Iringa Region, } \\
\text { Tanzania }\end{array}$ & $\begin{array}{l}(6-12 \times 4-7) \\
{[28-70]} \\
8-22\end{array}$ & $\begin{array}{l}(8-19 \times 4-9) \\
{[48-112]} \\
-\end{array}$ & Elongate & $\begin{array}{l}\text { Distortion of host cell } \\
\text { Displacement and } \\
\text { occasional distortion } \\
\text { of nuclei }\end{array}$ & {$[36]$} \\
\hline Trioceros werneri & $\begin{array}{l}\text { Plasmodium (Lacertamoeba) } \\
\text { arachniformis Telford, } 1988\end{array}$ & $\begin{array}{l}\text { Iringa Region, } \\
\text { Tanzania }\end{array}$ & $\begin{array}{l}(4-12 \times 2-7) \\
{[12-49]} \\
4-12\end{array}$ & $\begin{array}{l}(6-17 \times 3-8) \\
{[30-75]} \\
-\end{array}$ & $\begin{array}{l}\text { Elongate } \\
\text { and thin }\end{array}$ & $\begin{array}{l}\text { Hypertrophy } \\
\text { Displacement and } \\
\text { occasional distortion } \\
\text { of nuclei }\end{array}$ & {$[36]$} \\
\hline Triceros werneri & $\begin{array}{l}\text { Plasmodium (Lacertamoeba) } \\
\text { uzungwiense Telford, } 1988\end{array}$ & $\begin{array}{l}\text { Iringa Region, } \\
\text { Tanzania }\end{array}$ & $\begin{array}{l}(4-8 \times 3-6) \\
{[16-42]} \\
4-12\end{array}$ & $\begin{array}{l}(5-13 \times 3-7) \\
{[24-63]} \\
-\end{array}$ & Elongate & $\begin{array}{l}\text { Distortion of host cell } \\
\text { Displacement of nuclei } \\
\text { Enlargement of } \\
\text { proerythrocyte nucleus }\end{array}$ & {$[36]$} \\
\hline \multicolumn{8}{|l|}{ Cordylidae } \\
\hline $\begin{array}{l}\text { Cordylus t. tropidosternum } \\
\text { (Cope, 1869) } \\
\text { Other host: Cordylus vittifer } \\
\text { (Reichenow, 1887) }\end{array}$ & $\begin{array}{l}\text { Plasmodium (Carinamoeba) } \\
\text { cordyli Telford, } 1987\end{array}$ & $\begin{array}{l}\text { Tanga Region, } \\
\text { Tanzania }\end{array}$ & $\begin{array}{l}(4-7 \times 3-6) \\
{[12-36]} \\
4-11\end{array}$ & $\begin{array}{l}(5-8 \times 4-7) \\
{[12-28]} \\
-\end{array}$ & $\begin{array}{l}\text { Round or } \\
\text { ovoid }\end{array}$ & $\begin{array}{l}\text { Hypertrophy } \\
\text { Distortion of host cell } \\
\text { Distortion and } \\
\text { displacement of nuclei }\end{array}$ & {$[6,7]$} \\
\hline Cordylus vittifer & $\begin{array}{l}\text { Plasmodium (Lacertamoeba) } \\
\text { zonuriae (Pienaar, 1962) }\end{array}$ & $\begin{array}{l}\text { Elandsfontein, } \\
\text { South Africa } \\
\text { (this study) }\end{array}$ & $\begin{array}{l}\text { (undescribed); } \\
(7-17 \times 4-9) ;(12 \times 6.5) \\
\text { [undescribed]; } \\
{[36-120] ;[32-117]} \\
18-24 ; 12-28 ; 16-24\end{array}$ & $\begin{array}{l}(8-8.4 \times 4.2-4.6) ; \\
(7-20 \times 4-10) ;(13.5 \times 7) \\
\text { [undescribed]; } \\
{[42-114] ;[38-107]}\end{array}$ & Elongate & $\begin{array}{l}\text { Hypertrophy } \\
\text { Distortion and occasional } \\
\text { enlargement of host cell } \\
\text { Distortion and } \\
\text { displacement of nuclei }\end{array}$ & $\begin{array}{l}{[5]} \\
{[6]} \\
\text { This study }\end{array}$ \\
\hline $\begin{array}{l}\text { Pseudocordylus melanotus } \\
\text { (A. Smith, 1838) }\end{array}$ & $\begin{array}{l}\text { Plasmodium (Lacertamoeba) } \\
\text { intabazwe n. sp. }\end{array}$ & $\begin{array}{l}\text { Platberg, Harrismith, } \\
\text { South Africa }\end{array}$ & $\begin{array}{l}(3.8-6.5 \times 3.7-6.7) \\
{[11-26.9]} \\
8-14\end{array}$ & $\begin{array}{l}(5.5-7.1 \times 5.4-6.6) \\
{[32-46]} \\
-\end{array}$ & Kidney & $\begin{array}{l}\text { Slight displacement of } \\
\text { nuclei }\end{array}$ & This study \\
\hline \multicolumn{8}{|l|}{ Gekkonidae } \\
\hline $\begin{array}{l}\text { Cnemaspis barbouri Perret, } \\
1986\end{array}$ & $\begin{array}{l}\text { Plasmodium (Lacertamoeba) } \\
\text { cnemaspi Telford, } 1984\end{array}$ & $\begin{array}{l}\text { Morogoro Region, } \\
\text { Tanzania }\end{array}$ & $\begin{array}{l}(6-13 \times 3-7) \\
{[24-91]} \\
8-24\end{array}$ & $\begin{array}{l}(7-14 \times 3-9) \\
{[32-108]} \\
-\end{array}$ & $\begin{array}{l}\text { Elongate (active) } \\
\text { Ovoid or rounded } \\
\text { (chronic) }\end{array}$ & $\begin{array}{l}\text { Hypertrophy } \\
\text { Distortion of host cell } \\
\text { Displacement of nuclei }\end{array}$ & [25] \\
\hline $\begin{array}{l}\text { Hemidactylus platycephalus } \\
\text { Peters, } 1854\end{array}$ & $\begin{array}{l}\text { Plasmodium (Lacertamoeba) } \\
\text { uluguruense Telford, } 1984\end{array}$ & $\begin{array}{l}\text { Morogoro Region, } \\
\text { Tanzania }\end{array}$ & $\begin{array}{l}(4-10 \times 2-6) \\
{[12-54]} \\
4-12\end{array}$ & $\begin{array}{l}(5-10 \times 4-7) \\
{[20-63]} \\
-\end{array}$ & Ovoid & $\begin{array}{l}\text { Hypertrophy } \\
\text { Distortion of host cell } \\
\text { Enlargement and } \\
\text { displacement of nuclei }\end{array}$ & [25] \\
\hline $\begin{array}{l}\text { Lygodactylus capensis grotei } \\
\text { Sternfeld, } 1911\end{array}$ & $\begin{array}{l}\text { Haemocystidium lygodactyli } \\
\text { Telford, } 2005\end{array}$ & $\begin{array}{l}\text { University campus, } \\
\text { Morogoro, Tanzania }\end{array}$ & $\begin{array}{l}- \\
- \\
-\end{array}$ & $\begin{array}{l}(11-20 \times 4-9.5) \\
{[62-140]} \\
-\end{array}$ & & Distortion of host cell & [37] \\
\hline Lygodactylus capensis grotei & $\begin{array}{l}\text { Haemocystidium lygodactyli } \\
\text { Telford, } 2005\end{array}$ & $\begin{array}{l}\text { Morogoro region, } \\
\text { Tanzania }\end{array}$ & $\begin{array}{l}(5-10 \times 9-16) \\
{[20-70]} \\
6-26\end{array}$ & $\begin{array}{l}(8-25 \times 5-11) \\
- \\
-\end{array}$ & Elongate to oval & Distortion of host cell & {$[37]$} \\
\hline
\end{tabular}

\section{Cordylidae} (Reichenow, 1887)

Cordylus vittifer 
Table 1 African saurian malaria species across the families Agamidae, Chamaeleonidae, Cordylidae, Gekkonidae, Lacertidae, Opluridae and Scincidae (Continued)

\begin{tabular}{|c|c|c|c|c|c|c|c|}
\hline $\begin{array}{l}\text { Lizard host species by } \\
\text { family }\end{array}$ & Plasmodiid species & $\begin{array}{l}\text { Original host } \\
\text { localities }\end{array}$ & $\begin{array}{l}\text { Intracellular meront } \\
\text { dimensions }(L \times W \text { in } \mu \mathrm{m}) \text {; } \\
{\left[\mathrm{LW} \text { in } \mu \mathrm{m}^{2}\right] \text {; }} \\
\text { Number of merozoites }\end{array}$ & $\begin{array}{l}\text { Intracellular gametocyte } \\
\text { dimensions }(L \times W \text { in } \mu \mathrm{m}) \text {; } \\
\left.\text { [LW in } \mu \mathrm{m}^{2}\right]\end{array}$ & $\begin{array}{l}\text { Gametocyte } \\
\text { morphology }\end{array}$ & $\begin{array}{l}\text { Effects of gametocytes } \\
\text { on host cell }\end{array}$ & Reference \\
\hline $\begin{array}{l}\text { Lygodactylus I. luteopicturatus } \\
\text { Pasteur, } 1964 \\
\text { Other host: Lygodactylus } \\
\text { capensis grotei }\end{array}$ & $\begin{array}{l}\text { Plasmodium (Lacertamoeba) } \\
\text { loveridgei Telford, } 1984\end{array}$ & $\begin{array}{l}\text { Morogoro Region, } \\
\text { Tanzania }\end{array}$ & $\begin{array}{l}(5-15 \times 3-7) \\
{[20-91]} \\
6-26\end{array}$ & $\begin{array}{l}(8-23 \times 3-11) \\
{[48-176]} \\
-\end{array}$ & $\begin{array}{l}\text { Elongate, rarely } \\
\text { rounded }\end{array}$ & $\begin{array}{l}\text { Hypotrophy } \\
\text { Distortion of host cell } \\
\text { Displacement of nuclei }\end{array}$ & [25] \\
\hline $\begin{array}{l}\text { Tarentola mauritanica deserti } \\
\text { (Linnaeus, 1758) } \\
\text { Other host: Tarentola annularis } \\
\text { (Geoffroy De St-Hilaire, 1827) }\end{array}$ & $\begin{array}{l}\text { Haemocystidium tarentolae } \\
\text { (Parrot, 1927) Paperna \& } \\
\text { Landau, 1991 }\end{array}$ & El Kantara, Algeria & $\begin{array}{l}- \\
- \\
-\end{array}$ & $\begin{array}{l}(8-18 \times 4-12) \\
- \\
-\end{array}$ & Elongate & $\begin{array}{l}\text { Slight hypertrophy } \\
\text { and distortion of } \\
\text { host cell } \\
\text { Lateral displacement } \\
\text { of nuclei. }\end{array}$ & {$[38,39]$} \\
\hline \multicolumn{8}{|l|}{ Lacertidae } \\
\hline Holaspis guentheri Gray, 1863 & $\begin{array}{l}\text { Plasmodium (Lacertamoeba) } \\
\text { holaspi Telford, } 1986\end{array}$ & $\begin{array}{l}\text { Morogoro Region, } \\
\text { Tanzania }\end{array}$ & $\begin{array}{l}(5-13 \times 4-7) \\
{[25-66]} \\
8-18\end{array}$ & $\begin{array}{l}(6-18 \times 3-8) \\
{[28-98]} \\
-\end{array}$ & Elongate & $\begin{array}{l}\text { Distortion of host cell } \\
\text { Displacement and } \\
\text { distortion of nuclei }\end{array}$ & {$[40]$} \\
\hline \multicolumn{8}{|l|}{ Opluridae } \\
\hline Oplurus cuvieri Gray, 1831 & $\begin{array}{l}\text { Haemocystidium opluri } \\
\text { Paperna \& Landau, } 1991\end{array}$ & $\begin{array}{l}\text { Baie de Loukaio, } \\
\text { Madagascar }\end{array}$ & $\begin{array}{l}- \\
- \\
-\end{array}$ & $\begin{array}{l}(12-19 \times 3-12) \\
- \\
-\end{array}$ & Oblong, oval & $\begin{array}{l}\text { Lateral hypertrophy } \\
\text { Displacement of nuclei }\end{array}$ & [39] \\
\hline \multicolumn{8}{|l|}{ Scincidae } \\
\hline $\begin{array}{l}\text { Trachylepis maculilabris } \\
\text { (Gray, 1845) }\end{array}$ & $\begin{array}{l}\text { Plasmodium (Lacertamoeba) } \\
\text { maculilabre Schwetz, } 1931\end{array}$ & Kisangani, Congo & $\begin{array}{l}(10.0 \times 6.9) \\
{[69]} \\
15-20\end{array}$ & $\begin{array}{l}(7-13 \times 5-8) \\
{[42-91]} \\
-\end{array}$ & $\begin{array}{l}\text { Ovoid to } \\
\text { elongate }\end{array}$ & $\begin{array}{l}\text { Hypertrophy } \\
\text { Distortion of host cell } \\
\text { Displacement and } \\
\text { occasional distortion } \\
\text { of nuclei }\end{array}$ & [41] \\
\hline $\begin{array}{l}\text { Trachylepis quinquetaeniata } \\
\text { (Lichtenstein, 1823) } \\
\text { Other hosts: Trachylepis } \\
\text { maculilabris; Trachylepis striata } \\
\text { (Peters, 1844) }\end{array}$ & $\begin{array}{l}\text { Plasmodium (Carinamoeba) } \\
\text { mabuiae (Wenyon, 1909), } \\
\text { Telford, } 1983\end{array}$ & $\begin{array}{l}\text { Bahr-El-Ghazal } \\
\text { Province, Sudan }\end{array}$ & $\begin{array}{l}(4-9 \times 2-5 \\
{[10-30]} \\
4-12\end{array}$ & $\begin{array}{l}(5-11 \times 3-5) \\
{[18-44]} \\
-\end{array}$ & $\begin{array}{l}\text { Elongate, rarely } \\
\text { ovoid or round }\end{array}$ & $\begin{array}{l}\text { Hypertrophy } \\
\text { Occasional distortion } \\
\text { of host cell } \\
\text { Displacement and } \\
\text { occasional distortion } \\
\text { of nuclei }\end{array}$ & {$[31,42]$} \\
\hline Trachylepis striata & $\begin{array}{l}\text { Plasmodium (Sauramoeba) } \\
\text { heischi Garnham \& Telford, } \\
1984\end{array}$ & Nairobi, Kenya & $\begin{array}{l}(8-18 \times 6-11) \\
{[48-144]} \\
20-65\end{array}$ & $\begin{array}{l}(8-12 \times 4-9) \\
{[60-120]} \\
-\end{array}$ & $\begin{array}{l}\text { Large, } \\
\text { spindle-shaped }\end{array}$ & $\begin{array}{l}\text { Distortion of host cell } \\
\text { Lateral displacement } \\
\text { of nuclei }\end{array}$ & [43] \\
\hline $\begin{array}{l}\text { Trachylepis striata } \\
\text { Other hosts: Trachylepis } \\
\text { maculilabris; Trachylepis } \\
\text { quinquetaeniata; } \\
\text { Trachylepis varia } \\
\text { (Peters, 1867) }\end{array}$ & $\begin{array}{l}\text { Plasmodium (Lacertamoeba) } \\
\text { pitmani Hoare, } 1932\end{array}$ & $\begin{array}{l}\text { Lake Victoria, } \\
\text { Uganda }\end{array}$ & $\begin{array}{l}(4-11 \times 3-7) \\
{[12-66]} \\
4-25\end{array}$ & $\begin{array}{l}(5-16 \times 4-9) \\
{[25-91]} \\
- \\
2.07\end{array}$ & Ovoid & Distortion of nuclei & {$[44,45]$} \\
\hline
\end{tabular}

Abbreviations: $L$, length; $W$, width; $L W=L \times W ;-$ Indicates dimensions not recorded 
stain (FLUKA, Sigma-Aldrich, Steinheim, Germany). Subsequently, smears were screened with the aid of a $100 \times$ oil immersion objective, images captured and parasites measured as described previously [9-12]. Morphometric measurements [length (L) and width (W) in micrometres] of the developmental stages in the lizard erythrocytes were taken using Deltapix (Nikon, The Netherlands) software. Following the method of Telford [6], the area or size was calculated as (length $\times$ maximum width) (LW) (in $\left.\mu \mathrm{m}^{2}\right)$ for all parasite stages examined, and the relative size of meront and gametocyte stages to the host cell nucleus (LW/HNLW) and to the nuclei of uninfected host cells (LW/NNLW) determined. A few drops of blood were fixed in $2.5 \%$ glutaraldehyde for TEM, and the remaining blood, that was not used in blood smear preparation, was placed in sterile PCR microtubes (Eppendorf, Germany) with an equal volume of $70 \%$ ethanol to be processed molecularly at a future date.

\section{Transmission electron microscopy (TEM)}

Four to five drops of fresh blood were fixed in $2.5 \%$ glutaraldehyde $(0.2 \mathrm{M}, \mathrm{pH} 7.2)$ for $1 \mathrm{~h}$ at $4{ }^{\circ} \mathrm{C}$. Blood was pelleted by centrifugation $(10,000 \mathrm{rpm})$ and rinsed in $0.2 \mathrm{M}$ Sorensen's phosphate buffer and post fixed in $2 \%$ solution of osmium tetroxide in the same buffer. Samples were then dehydrated in a graded ethanol series, dried over a 4 molecular sieve and embedded in Agar 100 medium (Agar Scientific, Ltd., Stansted, UK). Thin sections, cut with a glass knife on an Ultracut III Ultramicrotome (Leica, Wetzlar, Germany) were collected on copper, 300 hexagonal-mesh grids and stained for 20 min in $10 \%$ uranyl acetate in Analar grade methanol, washed with Analar methanol and allowed to dry. Sections were then stained for 20 min in Reynolds' lead citrate solution, washed with $0.02 \mathrm{M}$ sodium hydroxide solution followed by distilled water, before examination with a Philips CM100 transmission electron microscope (Philips Electron Optics, Eindhoven, The Netherlands) operated at 80-100 kV. Digital images were captured with a MegaView II side mounted digital Olympus camera with accompanying iTEM software.

\section{DNA extraction and sequence analysis}

Ethanol-preserved blood from the nine parasitised individuals of the 77 collected of P. melanotus and both C. vittifer were used for molecular work. Genomic DNA of Plasmodium spp. was extracted from the samples following the standard protocol for the Kapa Express Extract kit (Kapa Biosystems, Cape Town, South Africa). Amplification of Plasmodium spp. DNA was initially completed using specific Plasmodium and Haemoproteus primer sets, with a nested-polymerase chain reaction (PCR) protocol targeting a fragment of the cytochrome- $b$ (cyt- $b$ ) gene as detailed in [13]. The PCR method consisted of two parts.
The primer set HAEMNF (5' -CAT ATA TTA AGA GAA TTA TGG AG-3') and HAEMNR2 (5'-AGA GGT GTA GCA TAT CTA TCT AC-3') was used first under the following conditions: initial denaturation at $94{ }^{\circ} \mathrm{C}$ for $3 \mathrm{~min}$, followed by 20 cycles, entailing a $94{ }^{\circ} \mathrm{C}$ denaturation for $30 \mathrm{~s}$, annealing at $50{ }^{\circ} \mathrm{C}$ for $30 \mathrm{~s}$ with an end extension at $72{ }^{\circ} \mathrm{C}$ for $45 \mathrm{~s}$, and following the cycles a final extension of $72{ }^{\circ} \mathrm{C}$ for $10 \mathrm{~min}$. This was followed by a second PCR using the primer set HAEMF (5'-ATG GTG CTT TCG ATA TAT GCA TG-3') and HAEMR2 (5'GCA TTA TCT GGA TGT GAT AAT GGT-3') [13]. The PCR conditions were as follows: initial denaturation at $94{ }^{\circ} \mathrm{C}$ for $3 \mathrm{~min}$, followed by 35 cycles, entailing a $94{ }^{\circ} \mathrm{C}$ denaturation for $30 \mathrm{~s}$, annealing at $50{ }^{\circ} \mathrm{C}$ for $30 \mathrm{~s}$ with an end extension at $72{ }^{\circ} \mathrm{C}$ for $45 \mathrm{~s}$, and following the cycles a final extension of $72{ }^{\circ} \mathrm{C}$ for $10 \mathrm{~min}$.

All PCR reactions were performed in a $25 \mu \mathrm{l}$ volume microtube, using $12.5 \mu \mathrm{l}$ Thermo Scientific DreamTaq PCR master mix $(2 \times)(2 \times$ DreamTaq buffer, $0.4 \mathrm{mM}$ of each dNTP, and $4 \mathrm{mM} \mathrm{MgCl} 2), 1.25 \mu \mathrm{l}$ of each primer, and at least $25 \mathrm{ng}$ of genomic DNA for the first PCR, and $1 \mu \mathrm{l}$ of the PCR product from the initial PCR for the second PCR. The remaining volume was made up of PCR-grade nuclease-free water (Thermo Scientific, Vilnius, Lithuania). The PCR reactions were undertaken in a Bio-Rad C1000 Touch ${ }^{\text {TM }}$ Thermal Cycler PCR machine (Bio-Rad, Hemel Hempstead, UK). Resulting amplicons were visualised by means of a $1 \%$ agarose gel stained with gel red (Biotium, USA) under UV light. The PCR products from each sample were sent to a commercial sequencing company (Inqaba Biotechnical Industries (Pty) Ltd. Pretoria, South Africa) for purification and sequencing in both directions. Resultant sequences were assembled using Geneious Ver. 7.1 (created by Biomatters. Available from http://www.geneious.com) and chromatogram-based contiguous sequences were generated, trimmed and manually corrected for ambiguous base calls. Sequences were identified using the Basic Local Alignment Search Tool (BLAST) [14], and deposited in the NCBI GenBank database under the accession numbers KX121601-KX121609.

Comparative sequences of Plasmodium species were downloaded from GenBank and aligned to the sequences generated within this study. Two species of Leucocytozoon, Leucocytozoon gentili and Leucocytozoon majoris (GenBank: DQ451435, DQ451439) were used as the outgroup, as species of Leucocytozoon were shown to be a sufficient outgroup of the focal taxa by [2]. All phylogenetic analyses were further undertaken in the bioinformatics software program Geneious Ver. 7.1. Sequences were aligned using the MUSCLE alignment tool [15]. To infer phylogenetic relationships a Bayesian inference (BI) method was used. A comprehensive model test was preformed to determine the most suitable nucleotide substitution model, according 
to the Akaike information criterion using jModelTest 2.1.7 $[16,17]$. The best-fit model selected was the General Time Reversible with estimates of invariable sites and a discrete Gamma distribution $(\mathrm{GTR}+\mathrm{I}+\Gamma)$. The dataset comprised 31 cytochrome $b$ (cyt- $b$ ) mitochondrial sequences, with an alignment length of $497 \mathrm{nt}$. The BI analysis was implemented from within Geneious 7.1 using MrBayes 3.2.2 [18]. The Markov Chain Monte Carlo (MCMC) algorithm was run for 10 million generations. The Markov chain was sampled every 100 cycles, and the MCMC variant contained 4 chains with a temperature of 0.2 . The log-likelihood values of the sample point were plotted against the generation time and the first $25 \%$ of the trees were discarded as 'burn-in' with no 'burn-in' samples being retained. Results were visualised in Trace (implemented from within Geneious) to assess convergence and the 'burn-in' period.

\section{Results}

\section{General observations}

Parasites of what appeared to be a Plasmodium species were discovered in the peripheral blood of 44/77 (prevalence $57 \%$ ) specimens of $P$. melanotus captured on various rocky outcrops on the summit of Platberg Reserve in the Eastern Free State. The peripheral blood of some lizards occasionally revealed mixed infections, comprising most likely Hepatozoon species, filarial nematode species and so-called Sauroplasma infections (unpublished data). Co-infections between the Plasmodium species and Hepatozoon species (of which there appeared to be possibly two species) were found in 27/77 (35\%) of the total lizards sampled. One of these Hepatozoon species was recently described as
Hepatozoon affluomaloti Van As, Davies \& Smit 2015, occurring in 14/77 (18\%) of the lizards [19].

Plasmodium zonuriae (Pienaar, 1962) infections were confirmed, based on morphological characteristics (see Table 1, Fig. 1 and Discussion), in both C. vittifer specimens (100\% prevalence) from the Roodewalshoek Conservancy, Mpumalanga. These infections from both lizard hosts were present in the peripheral blood erythrocytes (Figs. 1 and 2). No Plasmodium species, morphologically comparable to $P$. cordyli, were observed in either of the $C$. vittifer specimens or in any of the P. melanotus specimens.

\section{Plasmodium zonuriae (Pienaar, 1962) Telford, 1987}

Type-host: Cordylus vittifer (Reichenow, 1887) (Sauria: Cordylidae).

Vector: Unknown.

Type-locality: Elandsfontein (North-West province) [5]. Other localities: Pretoria (Gauteng) and Middelburg (Mpumalanga) [6]; Roodewalshoek (Mpumalanga) (present study).

Voucher material: Voucher material, $2 \times$ blood smears from Cordylus vittifer NMB P 414 and C. vittifer NMB P 415 , respectively, deposited in the Protozoan Collection of the National Museum, Bloemfontein (NMB), South Africa.

Representative DNA sequences: The cyt- $b$ gene sequences have been submitted in the GenBank database under the accession numbers KX121608 and KX121609.

\section{Redescription}

Trophozoite. Amoeboid forms (Fig. 1a) with abundant pseudopodia, measuring $1.8-2.8 \times 1.6-3.1 \quad(2 \pm$
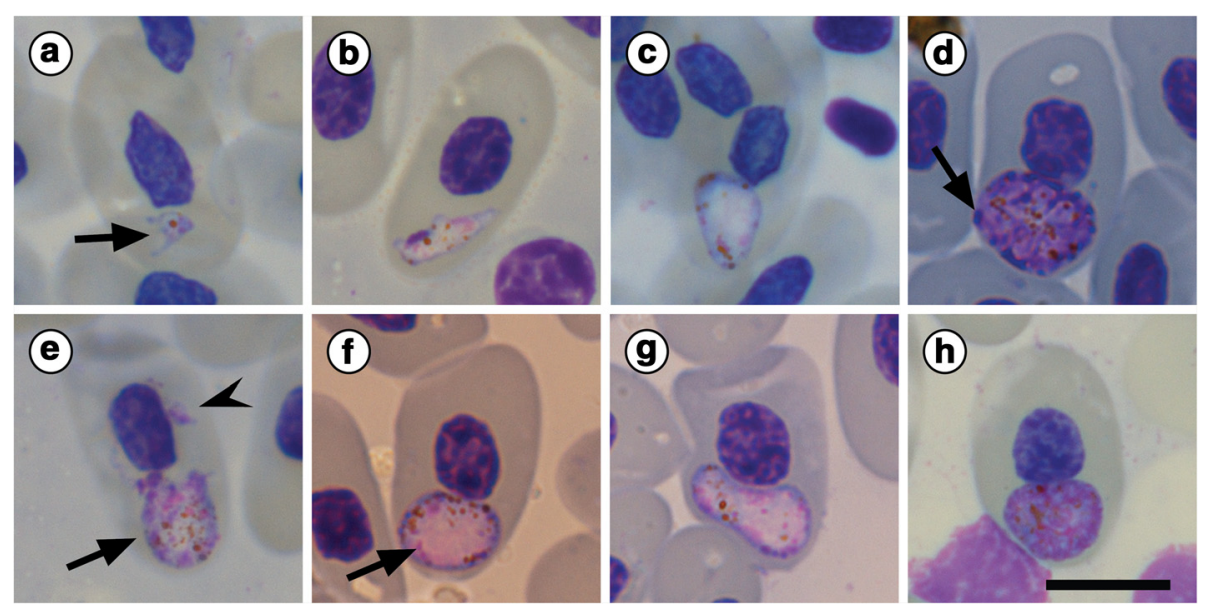

Fig. 1 Plasmodium zonuriae Pienaar 1962 Telford 1987 in the lizard Cordylus vittifer (Reichenow, 1887) (Sauria: Cordylidae). a Trophozoite with pseudopodia (arrow). b Maturing elongated trophozoite. c Early meront. d Meront producing 18 merozoites (arrow). e Mature meront (arrow) releasing merozoites (arrowhead). f Mature meront differentiating into microgametocyte with fine malarial pigment (arrow). $\mathbf{g}$ Macrogametocyte with evenly distributed pigment at its periphery. $\mathbf{h}$ Macrogametocyte with peripherally arranged dark chromatin strands. Images (a-h) captured from the voucher slides (NMB P NMB P 414 and NMB P 415). Scale-bar: $10 \mu \mathrm{m}$ 

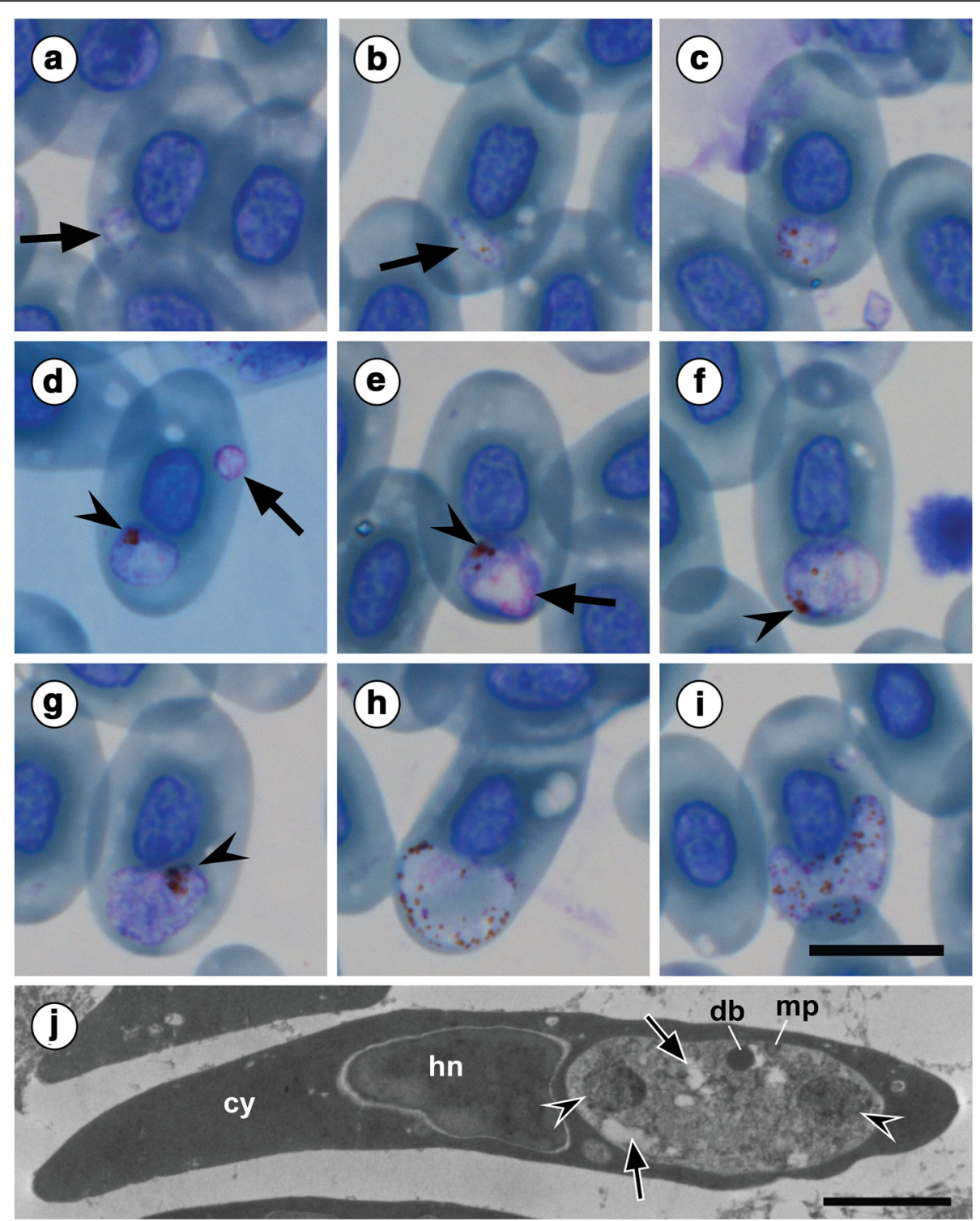

Fig. 2 Plasmodium intabazwe n. sp. in the lizard Pseudocordylus melanotus (A. Smith, 1838) (Sauria: Cordylidae). a Rounded trophozoite (arrow). b Oval-shaped trophozoite (arrow). c Immature broadly rounded meront with dark golden brown pigment granules dispersed throughout. d Rounded meront (arrowhead) with rounded trophozoite (arrow). e Meront with pigment granules (arrowhead) producing eight merozoites (arrow). f Meront with loosely aggregating pigment granules (arrowhead). g Kidney-shaped meront with clumped pigment granules (arrowhead). h Kidney-shaped microgametocyte with irregular pigment. i Macrogametocyte with evenly dispersed pigment. $\mathbf{j}$ Transmission electron micrograph of an infected erythrocyte containing a meront lying in a polar position with a surface micropore (mp), various intracytoplasmic vacuoles (arrows), and a dense body (db). Meront membrane is in direct contact with the host erythrocyte cytoplasm (cy). Images (a-i) captured from the hapantotype and parahapantotype slides (NMB P 412 and 413, respectively). Scale-bars: a-i, $10 \mu \mathrm{m} ; \mathrm{j}, 2$ mm

$0.9 \times 2.7 \pm 1.4) \mu \mathrm{m}(n=55)$, containing discrete brown or black pigment granules. Oval to pyriform forms with purple-stained periphery and pinkish central vacuole (Fig. 1e arrowhead) measuring 1.1-1.8 $\times 1.0-1.7$ (1.4 \pm $0.3 \times 1.2 \pm 0.35) \mu \mathrm{m}(n=60) ; \mathrm{LW}: 3.9-21.8(8.4 \pm 5) \mu \mathrm{m}^{2}$ $(n=60)$. Mature trophozoites elongated (Fig. 1b), with distinct purple staining peripheral areas, $3.0-4.6 \mu \mathrm{m}$ in diameter. Dark golden brown pigment granules dispersed throughout cytoplasm present.
Meront. Ovoid to pear-shaped (Fig. 1c), with slightly

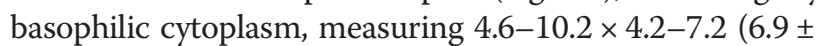
$1.3 \times 6.2 \pm 0.9) \mu \mathrm{m}(n=40)$, mostly polar in position within host cell cytoplasm. Dark golden brown pigment granules dispersed throughout meronts present (Fig. 1c), aggregating peripherally.

Mature meront. Polymorphic in shape (Fig. 1d-e), often slightly kidney shaped (Fig. 1d) to broadly oval (Fig. 1e), 
measuring 4.8-9.9 × 4.1-6.9 $(5.9 \pm 1.1 \times 5.8 \pm 0.9) \mu \mathrm{m}(n=$ 33); LW: $28-49.4(38.4 \pm 7) \mu \mathrm{m}^{2}$, with golden brown pigment granules aggregating either peripherally (Fig. 1d) or centrally within faintly eosinophilic cytoplasm (Fig. 1e). Meronts produced 12-25 (18.2 \pm 3.5$)(n=33)$ pink-stained merozoites (Fig. 1d arrow), lying at periphery. Ruptured meronts dispersed free purple-stained merozoites within host cell cytoplasm (Fig. 1e arrowhead). Meront size relative to host cell nucleus (LW/HNLW): $0.7-1.4(1.0 \pm 0.2)$ and to normal erythrocyte nuclei $(\mathrm{LW} /$ NNLW): 0.9-1.6 (1.2 \pm 0.2$)(n=50)$.

Gametocyte. Variable in shape, often oval to kidneyshaped, positioned in polar regions of host erythrocyte (Fig. 1f-g). Mature gametocytes, elongated or kidney-shaped, pale pink-stained, with fine malarial pigment (Fig. If arrow), or rounded with predominantly basophilic cytoplasm (Fig. 1f-g), producing strands of malarial pigment centrally (Fig. 1g) and peripherally (Fig. 1h).

Microgametocyte. Kidney-shaped, pale-staining (Fig. 1f), measuring 8.4-10.4 × 3.9-4.6 $(9.9 \times 4.1) \mu \mathrm{m}$; LW: $45.6-$ $55.5(52.0) \mu \mathrm{m}^{2}(n=18)$; tending to curve around host cell nucleus, sometimes slightly displacing it. Cytoplasm palepink, contains fine irregular brown to black pigment granules, loosely aggregating peripherally. Distinct pink staining nuclei aggregate peripherally (Fig. If arrow). Gametocyte size relative to host cell nucleus (LW/ HNLW): $1.3-2.3(1.7 \pm 0.4)$ and to normal erythrocyte nuclei (LW/NNLW): $1.7-2.9(2 \pm 0.5)(n=50)$.

Macrogametocyte. Deep basophilic staining, kidneyshaped, curving around nucleus (Fig. 1g) measuring 6.1$10.5 \times 6.2-7.9 \quad(10.1 \pm 1.1 \times 7.3 \pm 0.9) \quad \mu \mathrm{m} \quad(n=44) ; \quad \mathrm{LW}$ : 52.7-91.4 $(62.5 \pm 16) \mu^{2}$; with course, rounded darkbrown pigment often loosely clumped (Fig. 1g) or evenly dispersed centrally (Fig. 1h). Dark chromatin strands arranged peripherally (Fig. 1g-h). Macrogametocyte size relative to host cell nucleus (LW/HNLW): 1.6-2.0 (1.8 \pm 0.2 ) and to normal erythrocyte nuclei (LW/NNLW): 1.4$21.8(1.6 \pm 0.2)(n=50)$.

\section{Remarks}

Prior to this study, only two species of Plasmodium had been described parasitising cordylid lizards from South Africa, Plasmodium cordyli and Plasmodium zonuriae, originally described from cordylids of Tanzania and South Africa, respectively [6]. Infections of Plasmodium zonuriae (Pienaar, 1962) Telford, 1987 were confirmed in the type-host lizard in a new locality Roodewalshoek in the Mpumalanga Province. Telford [6] stated that he found $P$. cordyli infecting $C$. vittifer from the then Transvaal Province (incorporating the present
Mpumalanga Province), the same host and region from which $P$. zonuriae was originally described by Pienaar [5] and reported in this study. Thus it is possible that in future with the addition of more $C$. vittifer samples, we may be able to isolate $P$. cordyli for molecular analysis. Interestingly, Telford [6] described two morphological variants of $P$. cordyli, accounting for these differences as a result of parasitism of different host species.

\section{Plasmodium intabazwe n. sp.}

Type-host: Pseudocordylus melanotus (A. Smith, 1838) (Sauria: Cordylidae).

Vector: Unknown.

Type-locality: Donkey Pass ( $\left.28^{\circ} 16^{\prime} 28.99^{\prime \prime} \mathrm{S}, 2^{\circ} 12^{\prime} 21.39^{\prime \prime E}\right)$ (2,312 m), Platberg Reserve (Free State Province).

Other localities: Gibson Dam $\left(28^{\circ} 16^{\prime} 33.12 " \mathrm{~S}, \quad 2^{\circ}\right.$ $\left.12^{\prime} 40.13^{\prime \prime E}\right)(2,292 \mathrm{~m})$ and Platberg Pan $\left(28^{\circ} 14^{\prime} 35.28^{\prime \prime S}\right.$, $\left.29^{\circ} 09^{\prime} 47.02 " \mathrm{E}\right)(2,258 \mathrm{~m})$ across the summit of Platberg, Platberg Reserve (Free State Province).

Type-material: Hapantotype, $1 \times$ blood smear from Pseudocordylus melanotus deposited in the Protozoan Collection of the National Museum, Bloemfontein, South Africa under accession number NMB P 412; parahapantotype, $1 \times$ blood smear from Pseudocordylus melanotus; deposited in the Protozoan Collection of the National Museum, Bloemfontein (NMB), South Africa, under accession number NMB P 413.

Representative DNA sequences: The cyt- $b$ gene sequences have been submitted in the GenBank database under the accession numbers KX121601-KX121607.

ZooBank registration: To comply with the regulations set out in article 8.5 of the amended 2012 version of the International Code of Zoological Nomenclature (ICZN) [20], details of the new species have been submitted to ZooBank. The Life Science Identifier (LSID) of the article is urn:lsid:zoobank.org:pub:5BD63E9C-CA4C-4292-9AE2E0D79169259F. The LSID for the new name Plasmodium intabazwe is urn:lsid:zoobank.org:act:797829AA-9E9A-4C 98-B5A3-E4080DF9DBE2.

Etymology: The species epithet is derived from the Zulu word for 'flat mountain' since the first records of this malarial parasite were found in the blood of Pseudocordylus melanotus collected on Platberg (Afrikaans for 'flat mountain') in the eastern Free State, South Africa.

\section{Description}

Trophozoite. Rounded (Fig. 2a, d arrow) to oval (Fig. 2b arrow), with purple-stained periphery (Fig. 2a-b) and

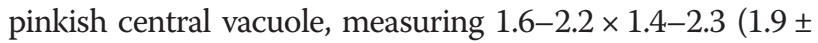
$0.1 \times 1.6 \pm 0.25) \mu \mathrm{m}(n=30)$; LW: $1.4-10.4(3.6 \pm 3) \mu \mathrm{m}^{2}$ $(n=50)$. 
Immature meront. Broadly rounded (Fig. 2c-d), sometimes amoeboid, stained deeper pink, measuring 4.2-5.5 $\times$ 2.4-5.2 $(4.9 \pm 0.3 \times 4.2 \pm 0.7) \mu \mathrm{m}(n=30) ; \mathrm{LW}: 6.7-20.8$ $(15.6 \pm 4.2) \mu^{2}(n=50)$; mostly polar in position within host cells. Dark golden-brown pigment granules dispersed throughout meronts present (Fig. 2c), often aggregating at one end (Fig. 2d arrowhead). Immature meront size relative to host cell nucleus (LW/HNLW): $0.2-0.6(0.5 \pm 0.1)$ and to normal erythrocyte nuclei (LW/NNLW): $0.2-0.6$ $(0.5 \pm 0.1)(n=50)$.

Mature meront. Polymorphic in shape (Fig. 2e-f), often oval (Fig. 2e) to rounded (Fig. 2f arrowhead), or kidneyshaped (Fig. 2g), measuring 3.8-6.5 × 3.7-6.7 (5.2 ×5.2) $\mu \mathrm{m}(n=18)$; LW: $25-44.4(34.5) \mu^{2}(n=18)$; with irregular dark-brown or black pigment granules often loosely aggregating at periphery (Fig. 2e-g arrowhead). Meronts produced 8-14 pink-staining nuclei (merozoites) (Fig. 2e arrow), lying at periphery. TEM micrographs of erythrocytes containing $P$. intabazwe $n$. sp. revealed a meront lying in a polar position in an erythrocyte (Fig. 2j). The meront was sectioned so that two nuclei (merozoites) were exposed. Also observable was a surface micropore (mp in Fig. 2j), various intracytoplasmic vacuoles (Fig. $2 \mathrm{j}$ arrows), and a structure resembling a dense body ( $\mathrm{db}$ in Fig. 2j). The meront showed no evidence of a parasitophorous vacuole, the parasite surface membrane being in direct contact with the host erythrocyte cytoplasm (cy in Fig. 2j). Mature meront size relative to host cell nucleus (LW/HNLW): 0.7-1.4 (1.1 \pm 0.3$)$ and to normal erythrocyte nuclei (LW/NNLW): 0.7-1.3 $(1 \pm 0.2)(n=50)$.

Gametocyte. Variable in shape, often kidney-shaped, positioned in polar regions of host erythrocyte (Fig. 2h-i). Later forms, elongated or kidney-shaped, pale pinkstained, with fine malarial pigment (Fig. 2h), or deeply purple-stained, containing coarse evenly distributed dark granules of malarial pigment (Fig. 2i).

Microgametocyte. Kidney-shaped to loosely oval (Fig. 2h), pale-staining, tending to curve slightly around host cell nucleus, measuring 6.5-7.7 × 3.6-4.1 $(6.9 \times 5.4)$ $\mu \mathrm{m}(n=8)$; LW: 47-57.5 (51.5) $\mu \mathrm{m}^{2}(n=8)$; seldom causing displacement of host cell nucleus. Fine irregularly shaped, dark-brown malarial pigment tends to aggregate peripherally (Fig. 2h). Diffuse pale-pink nuclei (Fig. 2h) often clumping at extremities of cytoplasm. Microgametocyte size relative to host cell nucleus (LW/HNLW): $1.5-2(1.7 \pm 0.2)$ and to normal erythrocyte nuclei (LW/ NNLW): $1.4-1.7(1.5 \pm 0.1)(n=50)$.

Macrogametocyte. Deep staining, elongate kidneyshaped, curving around the nucleus (Fig. 2i), with evenly dispersed dark-brown pigments, measuring 5.5-7.1 $\times$
5.4-6.6 $(6.4 \times 5.8) \quad \mu \mathrm{m} \quad(n=8) ; \mathrm{LW}: 52.7-91.5(62.5)$ $\mu \mathrm{m}^{2}(n=8)$. Macrogametocyte size relative to host cell nucleus (LW/HNLW): $0.01-1.5(1.1 \pm 0.4)$ and to normal erythrocyte nuclei (LW/NNLW): 0.01-1.4 (1.0 \pm 0.4) $(n=50)$.

\section{Remarks}

Observation of division stages within the peripheral blood, such as meronts, indicated that this parasite belongs to the genus Plasmodium, as compared to the closely related Haemocystidium, a genus of reptile plasmodiid parasite that shows no divisional stages within the peripheral blood (see [2, 6, 9]). Plasmodium intabazwe n. sp. has unique morphological and morphometric features when compared to the other two Plasmodium spp. from cordylids, P. cordyli and P. zonuriae (see Table 1). Trophozoites and young meront stages of $P$. cordyli could not be compared with those of $P$. intabazwe n. sp. as they were not described for $P$. cordyli. Meronts of $P$. intabazwe n. sp. are similar in appearance and size to those of $P$. cordyli infecting the type-host $C$. tropidosternum in that both species demonstrate polymorphic meronts [7], measuring (mean $5.2 \times 5.2$ vs $5.5 \times 4.5 \mu \mathrm{m}$ ), with merozoite numbers averaging eight and seven, respectively. However, meronts of $P$. intabazwe n. sp. do not possess the characteristic fanshape and are not strongly nucleophilic as was reported to be evident in $P$. cordyli meronts. Notably, meronts of $P$. cordyli in the South African C. vittifer also lack the tendency to be nucleophilic and furthermore, the characteristic fan-shaped meronts were described as rare. Also, meronts of $P$. cordyli infecting $C$. vittifer were even larger than meronts of $P$. cordyli infecting the type-host $C$. tropidosternum, as well as being larger than the meronts of $P$. intabazwe n. sp. at (mean $7.0 \times 5.6$ vs $5.0 \times 4.1$ vs $5.2 \times$ $5.2 \mu \mathrm{m}$, respectively) and contained more merozoites (mean 12 vs 7.5 vs 11, respectively). Gametocyte morphotypes of Plasmodium cordyli in both hosts, C. tropidosternum and $C$. vittifer, were reported by Telford [6] to be almost identical (dimorphic gametocytes were not reported), demonstrating rounded or ovoid gametocytes measuring on average $6.5 \times 5.5$ in C. tropidosternum vs $7.0 \times 5.5 \mu \mathrm{m}$ in $C$. vittifer, $[6,7]$ as compared to the kidney-shaped gametocytes of P. intabazwe n. sp. measuring on average $6.3 \times 6 \mu \mathrm{m}$, which are sexually dimorphic and easily distinguishable based on pigment distribution, size and staining properties.

Microscopical examinations of the meront and gametocyte morphology led to the identification of $P$. zonuriae. Even though there was a degree of variation in the sizes of these stages in $P$. zonuriae between descriptions (see Table 1) ([5,6], this study), there were common characteristic features. These include merozoite numbers (mean 18) and features such as the pigment granules being dispersed within both the meronts and gametocytes, 
and these stages curving around the host cell nucleus. Morphologically, trophozoite stages of $P$. intabazwe $\mathrm{n}$. sp. and $P$. zonuriae bore a close resemblance in size, trophozoites of both species measuring on average $\sim 1.9 \times$ $1.6 \mu \mathrm{m}$. Trophozoites of Plasmodium intabazwe n. sp. are polymorphic as are trophozoites of $P$. zonuriae. Furthermore, early meront stages of $P$. intabazwe n. sp. also resembled those of $P$. zonuriae in size and appearance, forming shapes from oval to elongated, or even on occasion amoeboid shapes. However, the division stages (meronts) in the peripheral blood of the two species differ. The meronts of $P$. intabazwe n. sp. contain eosinophilic cytoplasm with fine, yet abundant pigment that aggregates peripherally or centrally as compared to the division stages of $P$. zonuriae, which contain evenly distributed pigment at the periphery. Furthermore, meronts of $P$. intabazwe $\mathrm{n}$. sp. are overall smaller than the meronts of $P$. zonuriae (mean $5.2 \times 5.2$ vs $12.0 \times 6.5 \mu \mathrm{m}$ ) (unfortunately these dimensions were not provided in the original description of $P$. zonuriae [5]) see [6]. In addition, meronts of $P$. intabazwe n. sp. contain eight merozoites on average ( $v s 18$ in $P$. zonuriae) $[5,6]$. The gametocyte stages of $P$. intabazwe n. sp. and $P$. zonuriae also differed substantially. Gametocytes of $P$. intabazwe n. sp. are sexually dimorphic and usually kidney-shaped, measuring on average $6.3 \times 6.0 \mu \mathrm{m}$, and differ from $P$. zonuriae, which are usually elongated or rounded, measuring on average $10.9 \times 5.7 \mu \mathrm{m}([5,6]$, this study). Although microgametocyte stages of $P$. intabazwe n. sp. may at times resemble those of $P$. zonuriae in appearance and size, the pigment granules were in general much finer and evenly dispersed $([5,6]$, this study).

At a cytopathological level, erythrocytes infected with $P$. intabazwe n. sp. were neither hypertrophied nor dehaemoglobinized and rarely stained paler than non-infected cells. On the other hand, infections with $P$. zonuriae in $C$. vittifer are reported to have caused severe anaemic changes in the peripheral blood, causing hypertrophy, and displacing and distorting host cell nuclei $[5,6]$. However, these effects may not always be present, as reported for the meronts of $P$. zonuriae infecting its other host $P$. microlepidotus from the Western Cape Province, which caused little distortion of either the host cell or its nucleus. Similarly, P. intabazwe n. sp. also showed little effect on host cells, but in some cases meronts and gametocytes tended to curve around the host cell nucleus, though they never displaced or deformed it.

\section{Molecular analysis}

Amplicons of $500 \mathrm{nt}$ from Plasmodium zonuriae and Plasmodium intabazwe n. sp., were derived from the blood of two C. vittifer and seven P. melanotus, respectively. Sequences isolated in the current study from $P$. zonuriae and $P$. intabazwe $\mathrm{n}$. sp. confirmed the morphological observations by representing two distinct morphotypes, with an interspecific divergence of $3.4 \%$ based on 497 nt sequence comparisons (percentage of bases/identical residues). For the phylogenetic analysis, only a single nucleotide sequence from both $P$. zonuriae and $P$. intabazwe $\mathrm{n}$. sp. was used, as all the nucleotide sequences obtained in the current study from both $P$. zonuriae $(n=2)$ and P. intabazwe n. sp. $(n=7)$ were identical. These sequences were analysed together with sequences for 18 Plasmodium spp., four Haemoproteus spp., five Haemocystidium spp. and two Leucocytozoon spp. (used as the outgroup), all downloaded from the GenBank database (see Table 2).

The BI tree (Fig. 3) showed Plasmodium species isolated from lizard and bird hosts to be polyphyletic. Plasmodium species isolated from primate hosts were shown to form a well-supported monophyletic clade, forming a sister clade to Plasmodium chiricahuae (AY099061) and Plasmodium mexicanum (AY099060) isolated from North American lizard hosts. Haemoproteus species isolated from bird hosts formed a well-supported monophyletic clade separate from Plasmodium and Haemocystidium species. At the base of the phylogeny Haemocystidium species isolated from reptilian hosts were shown to be paraphyletic. The phylogenetic analysis confirmed the generic placement of the two species, $P$. zonuriae and $P$. intabazwe n. sp., within a large monophyletic clade consisting of only Plasmodium species. The two species from the current study were also shown to be closely related, forming a monophyletic clade with strong nodal support. Furthermore, these sequences clustered with Plasmodium species isolated from other lizard hosts.

\section{Discussion}

Plasmodium intabazwe n. sp. can be distinguished from other African cordylid malarial parasites, both morphologically in terms of not only its morphometric characteristics, but also its staining properties, distribution of pigment and cytopathology.

Even though the morphological findings strongly suggested that $P$. intabazwe $\mathrm{n}$. sp. is a different species to both $P$. cordyli and P. zonuriae, P. intabazwe and P. zonuriae did share similar morphological characteristics for a number of their peripheral blood life stages. This highlights the importance, when possible, of using both morphology and molecular characteristics in species descriptions. Even in cases where the morphology of two potential species is different, it is important to use molecular methods to differentiate them. As emphasized by Perkins [21], morphology of parasites can alter depending on the processing conditions of the slides, never mind the potential plasticity of the traditional characteristics used to differentiate these organisms. Unfortunately, the morphological findings could not be supported molecularly 
Table 2 List of organisms used in the phylogenetic analyses of this study according to associated host group, with associated GenBank accession numbers, host and references

\begin{tabular}{|c|c|c|c|c|}
\hline Group & Accession number & Parasite & Host & Reference \\
\hline \multirow[t]{11}{*}{ Plasmodium spp. of lizards } & AY099061 & P. chiricahuae & Sceloporus jarrovi & [46] \\
\hline & KR477583 & P. fairchildi & Norops cupreus & [47] \\
\hline & AY099059 & P. floridense & Anolis oculatus & [46] \\
\hline & EU834707 & P. gemini & Hypsilurus modestus & [48] \\
\hline & KX121601 & P. intabazwe n. sp. & Pseudocordylus melanotus & Current study \\
\hline & EU834704 & P. koreafense & Sphenomorphus jobiensis & [48] \\
\hline & EU834710 & P. lacertiliae & Emoia longicauda & [48] \\
\hline & EU834705 & P. megalotrypa & Sphenomorphus simus & [48] \\
\hline & AY099060 & P. mexicanum & Sceloporus occidentalis & [46] \\
\hline & EU834703 & P. minuoviride & Prasinohaema prehensicauda & [48] \\
\hline & KX121608 & P. zonuriae & Cordylus vittifer & Current study \\
\hline \multirow[t]{4}{*}{ Plasmodium spp. of birds } & JN164734 & P. circumflexum & Sylvia atricapilla & Unpublished \\
\hline & AF069611 & P. elongatum & Passer domesticus & [49] \\
\hline & AY099029 & P. gallinaceum & Gallus gallus & [46] \\
\hline & DQ659553 & P. relictum & Hemignathus virens & [50] \\
\hline \multirow[t]{5}{*}{ Plasmodium spp. of primates } & AF069605 & P. falciparum & Homo sapiens & [49] \\
\hline & AF069621 & P. knowlesi & Old World monkeys & [49] \\
\hline & AF069624 & P. malariae & Homo sapiens & [49] \\
\hline & AF069610 & P. reichenowi & Pan troglodytes & [49] \\
\hline & AF069619 & P. vivax & Homo sapiens & [49] \\
\hline \multirow[t]{4}{*}{ Haemoproteus spp. } & DQ630008 & H. balmorali & Muscicapa striata & [22] \\
\hline & DQ630010 & H. lanii & Lanius collurio & [22] \\
\hline & DQ630005 & H. pallidus & Ficedula hypoleuca & [22] \\
\hline & JN164722 & H. parabelopolskyi & Sylvia atricapilla & Unpublished \\
\hline \multirow[t]{5}{*}{ Haemocystidium spp. } & AY099062 & H. kopki & Teratoscincus scincus & [46] \\
\hline & KF049514 & H. mesnili & Naja annulifera & [2] \\
\hline & KF049506 & H. pacayae & Podocnemis unifilis & [2] \\
\hline & KF049492 & H. peltocephali & Podocnemis expansa & [2] \\
\hline & AY099057 & H. ptyodactylii & Ptyodactylus hasselquistii & [46] \\
\hline \multirow[t]{2}{*}{ Leucocytozoon spp. (outgroup) } & DQ451435 & L. gentili & Passer domesticus & [51] \\
\hline & DQ451439 & L. majoris & Fringilla coelebs & [51] \\
\hline
\end{tabular}

for $P$. cordyli. It would have been preferable to have molecularly compared $P$. cordyli to both the other species. However, if found in future through more extensive sampling, we would still be cautious in characterising this species as $P$. cordyli given that $C$. vittifer and South Africa are not the type-host or locality and given the morphological differences between the two variants.

The morphological findings regarding $P$. zonuriae and $P$. intabazwe n. sp. were further supported by the molecular data obtained for both species with an interspecific divergence of $3.4 \%$. Although [22] and [23] have suggested that the mean 'cut-off' for distinguishing between different Plasmodium and Haemoproteus species is an interspecies divergence of $5 \%$, a number of species such as Haemoproteus pallidus Valkiūnas \& Iezhova, 1991 and Haemoproteus minutus Valkiūnas \& Iezhova, 1992, with an interspecific divergence of approximately $1 \%$ in sequences of the cyt- $b$ gene, have been shown to be separate species when combining both morphological and molecular data (see [22, 24]).

In the phylogenetic analysis, $P$. zonuriae and $P$. intabazwe n. sp. were well nested within a larger monophyletic clade comprising only Plasmodium species. Although this clade contained moderate posterior probability support, the overall tree topology was similar to other studies such as [24], and particularly with a review on the closely 


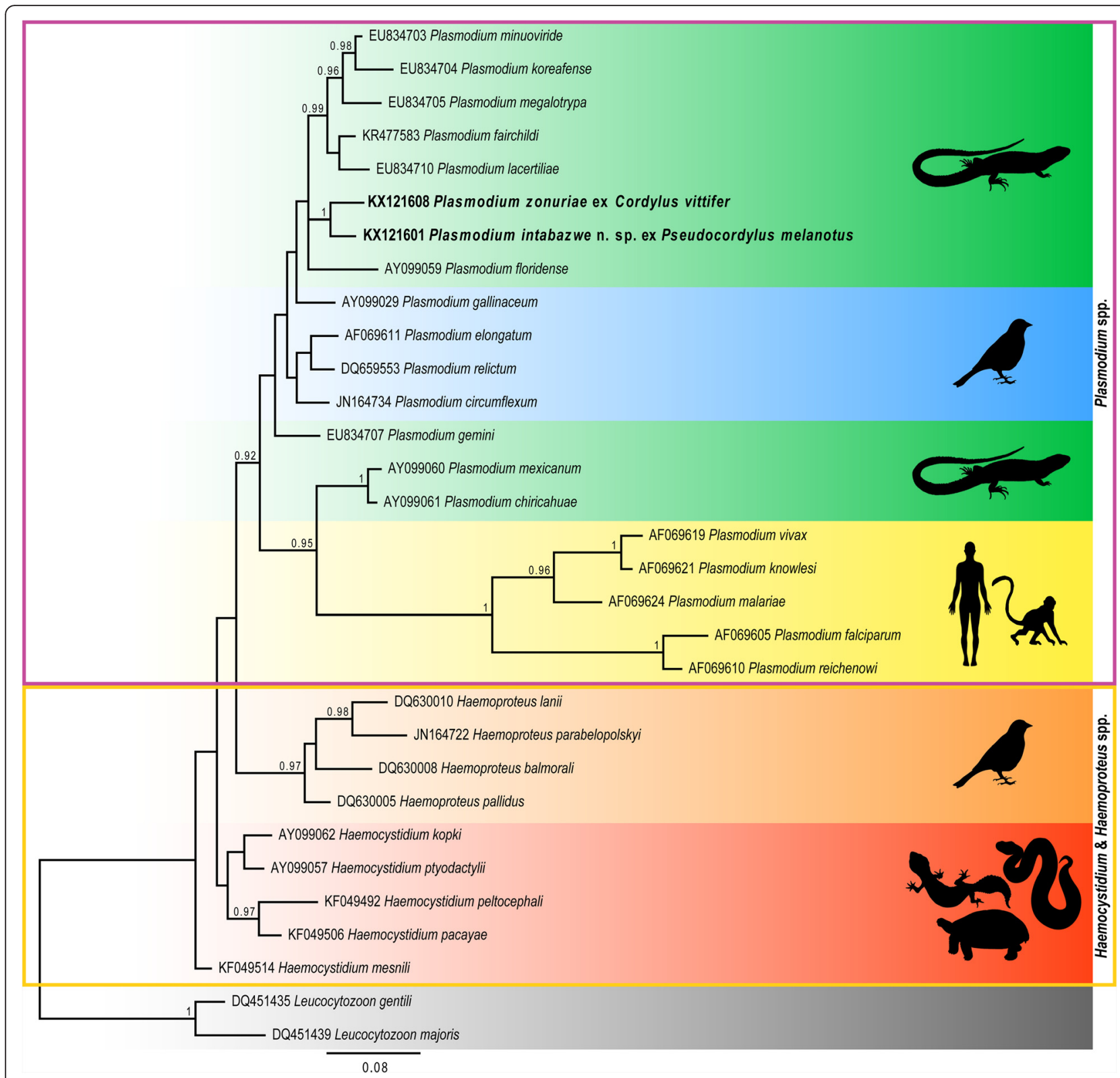

Fig. 3 Phylogenetic analysis of Plasmodium spp. and closely related protozoans based on cyt- $b$ gene sequences including sequences for Plasmodium intabazwe n. sp. and Plasmodium zonuriae generated in the present study (highlighted in bold). Bayesian inference (BI) analysis showing the phylogenetic relationships for 20 Plasmodium species, four Haemoproteus species, five Haemocystidium species and two Leucocytozoon species (used as the outgroup). All comparative sequences were downloaded form GenBank. Nodal support is provided by posterior probability values

related haemoprotid genera (see [2]). In the latter study, although the Haemoproteus spp. clade was shown to be the basal clade, the nodal support values separating the major Plasmodium species, Haemocystidium species and Haemoproteus species clades were all considerably higher. This was most likely attributable to the multigene and concatenated approach that was used for the phylogenetic analysis by [2], as compared to the current study's cyt- $b$ gene analysis, which is expected to provide a less robust analysis due to its variability.
Outside South Africa, and other than P. cordyli in Tanzania [7], P. intabazwe n. sp. is perhaps morphologically closest to Plasmodium uluguruense Telford, 1984 described from the gecko Hemidactylus platycephalus in the Uluguru Mountains, Tanzania [25]. Meronts of P. uluguruense, however, were more variable in size and measured on average $7 \times 4 \mu \mathrm{m}$, while meronts of $P$. intabazwe n. sp. were more constrained in their dimensions (mean $5.2 \times$ $5.2 \mu \mathrm{m})$. The gametocytes of the two species also differ, with those of $P$. uluguruense being larger and ovoid (mean 
$7.5 \times 5.5 \mu \mathrm{m})$, the pigment also not dispersed within the gametocytes, but rather forming an aggregate of dark greenish-yellow granules near the cell margin of both sexes of gametocytes. The smaller, microgametocytes of $P$. intabazwe n. sp. had distinct pigment distributed around the periphery of the parasites, measuring $(6.0-7.9 \times 3.5-5.6 \mu \mathrm{m})$. Microgametocytes of $P$. uluguruense were reported to be longer and larger than the macrogametocytes, measuring on average $8 \times 5 \mu \mathrm{m}$ [6].

Interestingly, as reported for P. microlepidotus during Pienaar's [5] study, in this study P. melanotus were also found to be parasitised by the prositigmatic mites Zonurobia semilunaris [26], although they occur in disjunctive localities. These mites were the only haematophagous invertebrates observed feeding on $P$. melanotus, warranting further study in future for developmental stages of $P$. intabazwe n. sp.

\section{Conclusions}

The molecular characterisation of $P$. intabazwe n. sp. along with that of $P$. zonuriae represents the first combined morphological description and molecular characterisation of South African saurian malarial parasites, additionally confirming their placement within Plasmodium. The detection and description of the sporogonic stages in the natural vector should also be a key consideration in future species descriptions. Future research should include the identification of possible definitive hosts or vectors such as mites and mosquitoes as well as experimental transmission studies. Most importantly however, this work increases biodiversity knowledge of saurian malarial parasites, which by adding to the known taxa, contributes to further studies into these organisms' taxonomy and phylogeny.

\section{Acknowledgements}

We are most grateful to the late Prof. Angela J Davies Kingston, University, UK, for aiding in the identification of saurian malaria parasite stages. We would like to thank Platberg Reserve and Roodewalshoek Conservancy, for access to sites for sample collection. In addition, we would like to thank Microbiology, Unit for Environmental Sciences, (NWU-P), for the use of their facilities.

\section{Funding}

The National Research Foundation (NRF) of South Africa provided funding to JVA (NRF Thutuka - Grant TTK: 14042266483), CAC (NRF Scarce Skills Postdoctoral Scholarship - Grant SFP13090332476), and ECN (NRF Scarce Skills Masters Scholarship - Grant UID: 89924). The role of the funding body was in the collection and analyses of data in this study. Opinions expressed and conclusions arrived at, are those of the authors and are not necessarily to be attributed to the NRF.

\section{Availability of data and material}

The datasets supporting the conclusions of this article are available in the NCBI (National Center for Biotechnology Information) repository under the GenBank accession numbers KX121601-KX121609, and the ZooBank repository under the life science identifier (LSID): urn:Isid:zoobank.org:pub:5BD63E9C-CA4C4292-9AE2-E0D79169259F.

\section{Authors' contributions}

All authors conceived and designed the project, participated in general data analysis and in drafting the manuscript. JVA carried out the fieldwork, prepared and examined blood smears, prepared light micrographs and compiled all measurement data. ECN participated in the molecular studies and in the sequence alignment and CAC provided significant support to the preparation of the manuscript. All authors read and approved the final manuscript.

\section{Competing interests}

The authors declare that they have no competing interests.

\section{Consent for publication}

Not applicable.

\section{Ethics approval and consent to participate}

This study received the relevant ethical approval from the North-West University Ethics Department (North-West University ethics approval no: NWU-00005-14-S3).

\section{Author details}

'Department of Zoology \& Entomology, University of the Free State, QwaQwa campus, Free State, South Africa. ${ }^{2}$ Unit for Environmental Sciences and Management, North-West University, Potchefstroom, South Africa. ${ }^{3}$ Laboratory of Aquatic Ecology, Evolution and Conservation, University of Leuven, 3000 Leuven, Belgium.

Received: 4 February 2016 Accepted: 14 July 2016

Published online: 08 August 2016

\section{References}

1. Davies AJ, Johnston MRL. The biology of some intraerythrocytic parasites of fishes, amphibians and reptiles. Adv Parasitol. 2000;45:1-107.

2. Pineda-Catalan O, Perkins SL, Peirce MA, Engstrand R, Garcia-Davila C, Pinedo Vasquez $M$, et al. Revision of hemoproteid genera and description and redescription of two species of chelonian hemoproteid parasites. J Parasitol. 2013;99:1089-98.

3. Garnham PCC. Malaria parasites and other haemosporidia. Oxford: Blackwell Science; 1966

4. Telford Jr SR. Plasmodia of reptiles. In: Kreier JP, editor. Parasitic protozoa. 2nd ed. San Diego: Academic; 1994. p. 1-71.

5. Pienaar UDEV. Haematology of some South African reptiles. Johannesburg: Witwatersrand University Press; 1962.

6. Telford SR. Hemoparasites of the Reptilia: Color Atlas and Text. New York: CRC Press; 2009

7. Telford Jr SR. Studies on African Saurian malarias: Plasmodium parasites of Cordylid lizards. Ann Parasitol Hum Comp. 1987;62:405-17.

8. Cook CA, Netherlands EC, Smit NJ. Redescription, molecular characterisation and taxonomic re-evaluation of a unique African monitor lizard haemogregarine Karyolysus paradoxa (Dias, 1954) n. comb. (Karyolysidae). Parasit Vectors. 2016;9:347.

9. Cook CA, Smit NJ, Davies AJ. Hemproteids (Apicomplexa: Haemoproteidae) from South African Tortoises (Cryptodiria: Testudinidae). J Parasitol. 2010;96: $1168-72$.

10. Van As J, Davies AJ, Smit NJ. Hepatozoon langii n. sp. and Hepatozoon vacuolatus n. sp. (Apicomplexa: Adeleorina: Hepatozoidae) from the crag lizard (Sauria: Cordylidae) Pseudocordylus langi from the North Eastern Drakensberg escarpment, Eastern Free State, South Africa. Zootaxa. 2013; 3608:345-56.

11. Netherlands EC, Cook CA, Smit NJ. Hepatozoon species (Adeleorina: Hepatozoidae) of African bufonids, with morphological description and molecular diagnosis of Hepatozoon ixoxo sp. nov. Parasitising three Amietophrynus species (Anura: Bufonidae). Parasit Vectors. 2014;7:552.

12. Netherlands EC, Cook CA, Kruger DJ, du Preez LH, Smit NJ. Biodiversity of frog haemoparasites from sub-tropical northern KwaZulu-Natal, South Africa. Int J Parasitol Parasites Wildl. 2015;4:135-41.

13. Waldenström J, Bensch S, Hasselquist D, Östman Ö. A new nested polymerase chain reaction method very efficient in detecting Plasmodium and Haemoproteus infections from avian blood. J Parasitol. 2004;90:191-4.

14. Basic Local Alignment Search Tool [http://blast.ncbi.nlm.nih.gov/Blast.cgi].

15. Edgar RC. Muscle: multiple sequence alignment with high accuracy and high throughput. Nucleic Acids Res. 2004;5:1792-7. 
16. Guindon S, Gascuel O. A simple, fast and accurate method to estimate large phylogenies by maximum-likelihood. Syst Biol. 2003;52:696-704.

17. Darriba D, Taboada GL, Doallo R, Posada D. jModelTest 2: more models, new heuristics and parallel computing. Nat Methods. 2012;9:772.

18. Huelsenbeck JP, Ronquist F. MrBayes: Bayesian inference of phylogenetic trees. Bioinformatics. 2001:17:754-5.

19. Van As J, Davies AJ, Smit NJ. Life cycle of Hepatozoon affluomaloti sp. n. (Apicomplexa: Haemogregarinidae) in crag lizards (Sauria: Cordylidae) and in culicine mosquitoes from South Africa. Folia Parasitol. 2015;62:008.

20. International Commission on Zoological Nomenclature. Amendment of articles 8, 9, 10, 21 and 78 of the International Code of Zoological Nomenclature to expand and refine methods of publication. Zootaxa. 2012;3450:1-7.

21. Perkins SL. Species concepts and malaria parasites: detecting a cryptic species of Plasmodium. Proc R Soc Lond B Biol Sci. 2000;267:2345-50.

22. Hellgren $\mathrm{O}$, Križanauskiene $\mathrm{A}$, Valkiūnas $\mathrm{G}$, Bensch $\mathrm{S}$. Diversity and phylogeny of mitochondrial cytochrome $b$ lineages from six morphospecies of avian Haemoproteus (Haemosporida: Haemoproteidae). J Parasitol. 2007;93:889-96.

23. Valkiūnas G, lezhova TA, Loiseau C, Smith TB, Sehgal RN. New malaria parasites of the subgenus Novyella in African rainforest birds, with remarks on their high prevalence, classification and diagnostics. Parasitol Res. 2009:104:1061-77.

24. Javanbakht H, Kvičerová J, Dvořáková N, Mikulícek P, Sharifi M, Kautman M, et al. Phylogeny, diversity, distribution, and host specificity of Haemoproteus spp. (Apicomplexa: Haemosporida: Haemoproteidae) of Palaearctic Tortoises J Eukaryot Microbiol. 2015;62:670-8.

25. Telford Jr SR. Haemoparasites of reptiles. In: Hoff GL, Frye FL, Jacobson ER, editors. Diseases of amphibians and reptiles. New York: Plenum Public Corporation; 1984. p. 385-517.

26. Lawrence RF. The prostigmatic mites of South African lizards. Parasitology. 1935;37:1-45

27. Theiler M. Special protozoological studies of the blood: protozoological studies of smaller animals in Liberia. In: Strong RP, editor. The African Republic of Liberia and the Belgian Congo, Harvard African Expedition. Cambridge: Harvard University Press; 1930. p. 490-8.

28. Bray RS. On the Parasitic Protozoa of Liberia. II. The Malaria Parasites of Agamid Lizards. J Eukaryot Microbiol. 1959:6:13-8.

29. Ball GH. Some blood sporozoa from East African reptiles. J Protozool. 1967; 14:198-210

30. Schall J. The ecology of lizard malaria. Parasitol Today. 1990;6:264-9.

31. Wenyon CM. Report of a travelling parasitologist and protozoologist. Rep Wellcome Res Labor, Khartum. 1909;3:121-68. dated 1908.

32. Petit G, Landau I, Boulard Y. Sporogonie de Plasmodium agamae chez Culicoides nubeculosus, au laboratoire: I - Expérimentation et description du cycle. Protistologica. 1983:19:537-41.

33. Telford Jr SR, Landau I. Plasmodium brygooi sp. n. from Chamaeleo brevicornis of Madagascar, with a redescription of Plasmodium robinsoni (Brygoo, 1962) from its type host and an additional host, Chamaeleo parsoni crucifer. Ann Parasitol Hum Comp. 1987;62:395-404.

34. Pringle G. Two new parasites from East African vertebrates. Trans R Soc Trop Med Hyg. 1960;54:411-4.

35. Ball GH, Pringle G. Plasmodium fisheri n. sp. from Chamaelio fisheri. J Protozool. 1965;12:479-82.

36. Telford Jr SR. Studies on African saurian malarias: five Plasmodium species from the Uzungwe Mountains of Tanzania. Int J Parasitol. 1988;18:197-219.

37. Telford Jr SR. A Haemocystidium species from the East African gecko Lygodactylus capensis grotei. J Parasitol. 2005;91:135-8.

38. Riding D. Haemoproteus of Tarentola annularis. Trans R Soc Trop Med Hyg. 1930;23:635-6.

39. Paperna I, Landau I. Haemoproteus (Haemosporidia) of lizards. Bull Mus Natl Hist Nat (Paris) 4me Sér. 1991;13:309-49.

40. Telford Jr SR. Studies on African saurian malarias: Plasmodium holaspi n. sp. from the flying lacertid Holaspis guentheri. J Parasitol. 1986;722:271-5.

41. Schwetz J. Sur quelques hématozoaires des lézards de Stanleyville et du Lac Albert. Ann Parasitol Hum Comp. 1931;9:193-201.

42. Telford Jr SR. Studies on African saurian malarias: Redescription of. Plasmodium mabuiae Wenyon, 1909 from Tanzanian skinks. J Parasitol. 1983;69:1146-9.

43. Garnham PC, Telford Jr SR. A new malaria parasite Plasmodium (Sauramoeba) heischi in skinks (Mabuya striata) from Nairobi, with a brief discussion of the distribution of malaria parasites in the family Scincidae. J Protozool. 1984;31:518-21.
44. Hoare CA. On protozoal blood parasites collected in Uganda. Parasitology. 1932;24:210-24.

45. Garnham PCC. Blood parasites of East African vertebrates, with a brief description of exo-erythrocytic schizogony in Plasmodium pitmani. Parasitology. 1950;40:328-37.

46. Perkins SL, Schall J. A molecular phylogeny of malarial parasites recovered from cytochrome $b$ gene sequences. J Parasitol. 2002;88:972-8.

47. Falk BG, Glor RE, Perkins SL. Clonal reproduction shapes evolution in the lizard malaria parasite Plasmodium floridense. Evolution. 2015;69:1584-96.

48. Perkins SL, Austin CC. Four new species of Plasmodium from New Guinea lizards: integrating morphology and molecules. J Parasitol. 2009:95:424-33.

49. Escalante AA, Freeland DE, Collins WE, Lal AA. The evolution of primate malaria parasites based on the gene encoding cytochrome $b$ from the linear mitochondrial genome. Proc Natl Acad Sci U S A. 1998;95:8124-9.

50. Beadell JS, Ishtiaq F, Covas R, Melo M, Warren BH, Atkinson CT, et al. Global phylogeographic limits of Hawaii's avian malaria. Proc R Soc Lond B Biol Sci. 2006:273:2935-44.

51. Martinsen ES, Paperna I, Schall JJ. Morphological versus molecular identification of avian Haemosporidia: an exploration of three species concepts. Parasitology. 2006:133:279-88

\section{Submit your next manuscript to BioMed Central and we will help you at every step:}

- We accept pre-submission inquiries

- Our selector tool helps you to find the most relevant journal

- We provide round the clock customer support

- Convenient online submission

- Thorough peer review

- Inclusion in PubMed and all major indexing services

- Maximum visibility for your research

Submit your manuscript at www.biomedcentral.com/submit
() BioMed Central 